\title{
PENINGKATAN MOTIVASI DAN HASIL BELAJAR MATERI MASALAH-MASALAH EKONOMI MELALUI PEMBELAJARAN KOOPERATIF MODEL ICE BREAKING
}

\section{THE IMPROVEMENT OF MOTIVATION AND LEARNING OUTCOMES OF ECONOMIC ISSUES MATERIALS THROUGH LEARNING COOPERATIVE ICE BREAKING MODEL}

\author{
Anik Hastiyaningsih \\ Sekolah Menengah Atas Negeri 3 Pati \\ Email : anik.hastiyaningsih@gmail.com
}

\begin{abstract}
The learning outcomes on the economic issues material of the students in the grade 10th social-3 SMAN 3 were low. It was indicated that the students had low motivation to learn that material. Therefore, the teacher applied ice breaking as a learning method to promote students' motivation and learning outcomes. This research aimed to compare students' motivation and learning outcomes on economic issue material before and after the application of ice breaking model. It used action class approach, in which 36 students participated as respondents. It comprised two cycles, which each cycle consisted of four stages, namely: planning, action, observation, and reflection. Data were collected through test and observation and then were analyzed using the quantitativequalitative descriptive method. The research concluded: (1) the students showed higher motivation on learning activities after the researcher applied ice breaking method. They paid more attention and were active answering questions; and (2) there was the increase in the students' learning outcomes, i. e, 62.08 on precycle; 70.28 on cycle I; and 76.81 on cycle II. Furthermore, the number of students passed the standard of minimum completion (KKM) increased as well, that were 10 students in precycle, 20 students in cycle I, and 31 students in cycle II.
\end{abstract}

Keywords: economic issues material, ice breaking, learning outcome, motivation.

\section{ABSTRAK}

Hasil belajar kelas X IPS3 SMAN 3 tentang materi masalah-masalah ekonomi cenderung rendah. Para siswa memiliki motivasi yang rendah dalam mempelajari materi tersebut. Oleh karena itu, guru menerapkan metode belajar ice breaking untuk meningkatkan motivasi dan hasil belajar siswa. Tujuan penelitian adalah membandingkan motivasi dan hasil belajar siswa sebelum dan sesudah penggunaan metode ice breaking. Penelitian ini menggunakan metode tindakan kelas, dengan menyertakan 36 siswa sebagai subjek penelitian.peneltiandilakukan dalam dua Siklus, dimana setiap Siklus terdiri dari empat tahap, yaitu perencanaan, penerapan, observasi, dan refleksi. Pengumpulan data menggunakan tes dan observasi, selanjutnya data diolah dengan metode deskriptif kuantitatif-kualitatif. Hasil penelitian adalah (1) para siswa menunjukkan motivasi yang lebih tinggi setelah penerapan ice breaking, tercermin dalam perhatian yang lebih baik selama pembelajaran dan keaktifan dalam menjawab soal; dan (2) terjadi peningkatan hasil belajar, yaitu 62,08 pada kondisi awal, 70,28 pada Siklus I, dan 76,81 pada Siklus 2. Selain itu, jumlah siswa yang memenuhi KKM juga meningkat, yaitu 10 siswa pada kondisi awal,20 siswa pada Siklus I, dan 31 siswa pada Siklus II.

Kata kumci: materi masalah-masalah ekonomi, ice breaking, hasil belajar, motivasi 


\section{PENDAHULUAN}

Salah satu standar kompetensi pelajaran ekonomi berdasarkan silabus yang disusun guru-guru ekonomi SMA Negeri 3 Pati adalah materi masalahmasalah ekonomi. Nilai ulangan harian siswa kelas X IPS3 semester 2 SMA 3 Pati menunjukkan hasil yang sangat rendah. Siswa yang tuntas dengan KKM 75 hanya 10 siswa dari 36 siswa $(27,78 \%)$ dengan rerata nilai 62,08 . Kondisi ini menunjukkan daya serap rendah $(28,77 \%)$ dan ketuntasan secara klasikal juga rendah karena kurang dari $85 \%$.

Selama ini guru menggunakan metode ceramah dan penugasan dalam proses pembelajaran ekonomi dan ternyata hasil belajar siswa rendah. Padahal mata pelajaran ekonomi merupakan mata pelajaran ciri khusus program IPS dan sebagai salah satu pelajaran yang masuk ujian Nasional. Berdasarkan hasil belajar yang rendah dan kesulitan siswa dalam belajar maka guru perlu meningkatkan hasil belajar serta memberi motivasi belajar agar hasil belajar meningkat. Salah satu cara dalam proses pembelajaran yang dilaksanakan dalam penelitian adalah dengan Metode Ice Breaking.

Salah satu metode pembelajaran yang diduga dapat meningkatkan hasil belajar adalah Metode Ice Breaking. Kelebihan metode Ice Breaking yaitu siswa menjadi termotivasi dan bersemangat atas permainan dan humor pada saat pembelajaran sehingga tidak bosan dan mengantuk. (Kurniasih \& Alarifin, 2015).

Tujuan penelitian ini untuk membandingkan hasil belajar dan motivasi siswa pada materi masalahmasalah ekonomi sebelum dan sesudah menggunakan Metode Ice Breaking Diharapkan agar guru selalu berinovasi dalam menggunakan metode mengajar antara lain dengan Metode Ice Breaking.

\section{TINJAUAN PUSTAKA}

\section{Hakekat Motivasi}

Motivasi adalah dorongan kerja yang timbul pada diri seseorang untuk berperilaku dalam mencapai tujuan yang telah ditentukan. Fungsi motivasi menurut Hamalik, (1990) adalah untuk mendorong timbulnya kelakuan atau sesuatu perbuatan berfungsi sebagai pengaruh

Menurut Mc. Donald (dalam Hamalik, 2001) mendefinisikan motivasi sebagai perubahan energi dalam diri (pribadi) seseorang yang ditandai dengan timbulnya perasaan dan reaksi untuk mencapai tujuan yaitu; (1) Motivasi dimulai dari adanya perubahan energi dalam pribadi; (2) Motivasi ditandai dengan timbulnya perasaan; (3) Motivasi ditandai dengan reaksi-reaksi untuk mencapai tujuan.

Cara menimbulkan motivasi siswa dalam belajar: (1) Kemukakan tujuan yang hendak dicapai kepada siswa agar mendapat perhatian mereka, Tunjukkan hubungan-hubungan, kunci agar siswa benar-benar memahami apa yang sedang diperbandingkan, Menjelaskan pengertian secara nyata, diusahakan menggunakan media instruksional sehingga lebih memperjelas masalah yang sedang dibahas,(4) Hindarilah pembicaraan dari hal-hal yang abstrak yang berada di luar jangkauan pikiran siswa, kecuali kita menggunakan alat bantu tertentu, (5) Usahakan agar siswa mengajukan pertanyaan-pertanyaan agar terjadi komunikasi secara timbal balik (Hamalik, 1990).

\section{Hakekat Hasil Belajar Masalah- masalah Ekonomi}

Belajar adalah modifikasi atau memperteguh kelakuan melalui pengalaman. Belajar merupakan suatu proses, suatu kegiatan dan bukan suatu hasil atau tujuan (Hamalik, 1990). 
Menurut Sudjana (2005) hasil belajar adalah perubahan tingkah laku, yaitu kemampuan yang dimiliki siswa setelah ia melaksanakan proses belajar mengajar. Faktor-faktor yang mempengaruhi hasil belajar: (1) Jenis mata pelajaran; (2) Faktor lingkungan siswa; (3) Keadaan individu siswa; dan (4) Proses belajar mengajar. Adapun masalah-masalah Ekonomi meliputi: (1) inflasi; (2) pengangguran; (3) kemiskinan; (4) pengelolaan SDA; (5) korupsi; (6) transmigrasi tidak merata; dan (7) distribusi.

\section{Pembelajaran Kooperatif Metode Ice Breaking.}

Ice breaking adalah suatu aktivitas kecil dalam suatu acara yang bertujuan agar peserta acara mengenal peserta lain dan merasa nyaman dengan lingkungan barunya. Kegiatan ini biasanya berupa suatu humor, kadang berupa kegiatan yang cenderung memalukan, kegiatan berupa informasi, pencerahan, atau dapat juga dalam bentuk permainan sederhana. Kalau dipilih kegiatan yang cocok, Ice Breaking bisa menjadi metode yang efektif untuk meningkatkan hasil belajar siswa berupa memberi salam, perkenalan, juga kesigapan dan konsentrasi, mengingat warna, gerak lagu, tepuk tangan tunggal ganda dan lakukan yang guru katakan (Irachmat, 2015).

\section{METODE PENELITIAN}

\section{Metode penelitian menggunakan pendekatan deskriptif kualitatif (Arikunto, 1999). Penelitian ini dilakukan selama empat bulan, yaitu bulan Januari 2017 sampai dengan bulan April 2017 dimulai dengan menyusun proposal, instrumen penelitian, mengambil data Siklus I dan Siklus II, menganalisis data dan diakhiri dengan menyusun laporan hasil penelitian. Kendala penelitian yang dihadapi adalah adanya Try Out dan USBN serta UNBK}

menyebabkan peneliti tidak dapat mengambil data sebab kelas $\mathrm{X}$ belajar di rumah.

Subyek penelitian tindakan kelas ini adalah siswa kelas X IPS 3 berjumlah 36 orang terdiri dari 11 orang laki-laki dan 25 orang perempuan. Pengambilan data penelitian dilakukan tiga kali yaitu data kondisi awal, data Siklus I dan data Siklus II. Data penelitian meliputi data hasil tes tertulis dan data motivasi. Tes tertulis dilaksanakan tiga kali yaitu: (1) Tes tertulis kondisi awal, dengan soal esai sebanyak 5 soal, (2) Tes tertulis Siklus I, terdiri dari 5 soal esai, (3) Tes tertulis Siklus II, terdiri dari 5 soal esai.

Adapun data motivasi diambil dari hasil pengamatan teman sejawat sebagai kolaboran mengenai minat, sikap, perhatian sebagai kriteria motivasi pada saat kegiatan pembelajaran. Pengambilan data motivasi diambil 2 kali yaitu pada Siklus I dan Siklus II. Validasi data menggunakan validasi kualitatif. menggunakan diskriptif yaitu dengan membandingkan: (1) Nilai tes kondisi awal dengan nilai tes pada Siklus I, (2) Nilai tes Siklus I dengan nilai tes pada Siklus II, (3) Nilai tes pada kondisi awal dengan nilai tes pada kondisi akhir.

Data kuantitatif dianalisis dengan menggunakan diskriptif kualitatif dengan cara membandingkan hasil pengamatan motivasi Siklus I dengan Siklus II dan hasil pengamatan awal dengan akhir. Siklus I dan II dilaksanakan dua kali pertemuan atau 4 jam pelajaran dengan kegiatan sebagai berikut: planning (perencanaan tindakan), acting (pelaksanaan tindakan), observing (pengamatan tindakan) dan reflecting (refleksi).

Kegiatan pada Siklus I dilakukan suatu tindakan dengan cara membentuk kelompok besar. Tiap kelompok terdiri dari 12 siswa. Jumlah siswa kelas XIPS 3 ada 36 anak dan dibagi menjadi 3 kelompok. Kegiatan pembelajaran pada 
pertemuan kesatu guru mempresentasikan materi KD (Kompetensi Dasar) Masalah-masalah Ekonomi lalu memberi tugas perkelompok untuk mendiskusikan dan mengerjakan secara bersama-sama. Selanjutnya pada pertemuan kedua, siswa melanjutkan diskusi dan menjelaskan unjuk kerja atau lembar kerja secara bersama-sama secara berkelompok. Setelah satu KD selesai disampaikan dalam 2 kali pertemuan, selanjutnya dilakukan tes.

Menurut pengamatan teman sejawat, dalam kegiatan pembelajaran pada Siklus I ini terlihat hanya ada beberapa siswa yang aktif, minat dan perhatian, sehingga motivasi belajar masih kurang. Hal ini disebabkan jumlah siswa dalam kelompok masih terlalu banyak, tiap kelompok 12 siswa.

Kegiatan pembelajaran pada Siklus II juga menggunakan pembelajaran kooperatif Metode Ice Breaking namun sudah diperbaiki dengan membentuk kelompok kecil yang terdiri dari 6 siswa. Guru memberikan bimbingan dalam melaksanakan materi kepada kelompok kecil untuk menambah motivasi belajar. Setiap kelompok diharapkan benar-benar bisa memahami konsep materi.

Kegiatan pembelajaran pertemuan kesatu, guru mempresentasikan materi KD Masalah-masalah Ekonomi menyusun kertas kerja secara singkat melalui peta konsep. Selanjutnya guru memberi tugas perkelompok untuk mendiskusikan dan mengerjakan secara individu per kelompok. Kegiatan pada pertemuan kedua, siswa secara berkelompok melanjutkan diskusi dan mengerjakan unjuk kerja atau lembar kerja dengan bimbingan guru sampai semua anggota kelompok dapat memahami konsep materi. setelah selesai satu KD, maka akan dilaksanakan tes bagi siswa yang memperoleh nilai tertinggi diberi penghargaan.

\section{HASIL DAN PEMBAHASAN}

\section{Deskripsi Kondisi Awal}

Guru masih menggunakan metode pembelajaran yang konvensional dalam kegiatan pembelajaran kondisi awal ini,. Pembelajaran hanya menggunakan metode ceramah dan penugasan serta dilakukan secara klasikal. Pembelajaran monoton, masih searah dari guru, semua kegiatan terpusat pada guru, banyak siswa yang kurang memperhatikan sehingga kegiatan pembelajaran nampak kurang aktif. Siswa kurang memahami materi yang dibahas karena kurang memperhatikan akibatnya hasil belajar siswa rendah.

Rendahnya hasil belajar siswa tersebut dapat dilihat dari hasil tes pada kondisi awal, dengan KD 5,5 tentang melakukan posting dari jurnal ke buku besar, nilai rata-ratanya 62,08 , nilai terendah 40 dan nilai tertinggi 80 . Berdasarkan hasil pengamatan teman sejawat, dalam kegiatan pembelajaran pada kondisi awal ini terlihat hanya ada beberapa siswa yang aktif, memiliki minat dan perhatian.

Motivasi dalam belajar dilihat dari keaktifan, minat dan perhatian siswa dalam mengikuti proses belajar. Jumlah siswa yang aktif hanya 5 siswa atau $13,89 \%$ dan jumlah siswa yang nampak mempunyai minat ada 7 siswa atau $19,44 \%$ serta jumlah siswa yang mempunyai perhatian ada 10 siswa atau $27,78 \%$.

Proses belajar pada kondisi awal motivasi belajar siswa sangat rendah. Karena dari 36 siswa hanya ada 5 siswa yang aktif dan dari 36 siswa hanya ada 7 siswa yang nampak mempunyai minat. Jumlah siswa yang tuntas dengan KKM 
75 sebanyak 10 siswa dan jumlah siswa yang belum tuntas ada 26 siswa.

\section{Deskripsi Siklus I}

Refleksi tindakan hasil tes ini dilakukan dengan membandingkan antara hasil tes pada kondisi awal dengan hasil tes pada Siklus I. Perbandingan ini dapat dilihat dalam Tabel 1.

Tabel 1

Hasil Tes Kondisi Awal

\begin{tabular}{lrrr}
\hline Nilai & $\begin{array}{c}\text { Kondisi } \\
\text { Awal }\end{array}$ & Siklus I & $\begin{array}{c}\% \\
\text { Kenaikan }\end{array}$ \\
\hline Tinggi & 80 & 90 & 12,5 \\
Rendah & 40 & 55 & 37,5 \\
\hline Rerata & 62,08 & 70,28 & 13,21 \\
\hline
\end{tabular}

Sumber : Data primer (2017)

Setelah dilakukan tindakan yaitu pembelajaran kooperatif Metode Ice Breaking, pada kegiatan pembelajaran Siklus I diperoleh nilai tertinggi 90, nilai terendah 55 dan nilai rata-rata 70,28. Terdapat kenaikan nilai tertinggi dari kondisi awal ke Siklus I sebesar 10 atau $12,50 \%$. Untuk nilai terendah, ada kenaikan sebesar 15 atau $37,50 \%$ dari kondisi awal ke Siklus I. Nilai rata-rata kondisi awal ke Siklus I mengalami kenaikan sebesar 8,2 atau 13,21\%.

Refleksi tindakan mengenai ketuntasan belajar juga dapat dilihat dari perkembangan pencapaian ketuntasan belajar kondisi awal dan Siklus I. Dengan KKM 75, jumlah siswa yang tuntas belajar antara kondisi awal dengan siklus I mengalami kenaikan sebesar 10 atau 27,78\%. Pada kondisi awal, jumlah siswa yang tuntas hanya 10 siswa sedangkan setelah ada tindakan melalui pembelajaran kooperatif Metode Ice Breaking pada siklus I, siswa yang tuntas menjadi 20 siswa. Setelah dilakukan tindakan, jumlah siswa yang belum tuntas mengalami penurunan dari 26 siswa menjadi 16 siswa.
Refleksi tindakan hasil motivasi dilakukan dengan membandingkan hasil pengamatan mengenai keaktifan, minat, perhatian sebagai unsur motivasi antara kondisi awal dengan siklus I. Hasil pengamatan teman sejawat pada kondisi awal, nampak hanya 5 siswa yang aktif, 7 siswa yang minat dan 10 siswa yang perhatian. Pada siklus I setelah diterapkan pembelajaran kooperatif Metode Ice Breaking, ada 10 siswa yang aktif, 16 siswa yang minat dan 22 siswa yang perhatian. Perbandingan data ini dapat dilihat pada Tabel 2.

\section{Tabel 2}

Motivasi Kondisi Awal dan Siklus I

\begin{tabular}{lccc}
\hline $\begin{array}{c}\text { Unsur } \\
\text { Motivasi }\end{array}$ & $\begin{array}{c}\text { Kondisi } \\
\text { Awal }\end{array}$ & Siklus I & $\begin{array}{c}\% \\
\text { Kenaikan }\end{array}$ \\
\hline Aktif & 5 & 10 & 100 \\
Minat & 7 & 16 & 129 \\
Perhatian & 10 & 22 & 120 \\
\hline
\end{tabular}

Sumber : Data primer (2017)

Berdasarkan Tabel 2, dapat diketahui bahwa hasil pengamatan mengenai motivasi belajar yang dilihat dari keaktifan, minat dan perhatian antara kondisi awal dengan Siklus I masingmasing mengalami kenaikan. Untuk keaktifan ada kenaikan 5 atau 100\%, untuk minat ada kenaikan 9 atau $129 \%$ dan untuk perhatian ada kenaikan 12 atau $120 \%$.

\section{Deskripsi Siklus II}

Refleksi tindakan hasil tes ini dilakukan dengan membandingkan antara hasil tes pada Siklus I dengan hasil tes Siklus II. Hasil tes pada Siklus I nilai tertinggi 90, nilai terendah 55 dan nilai rata-rata 70,28. Pada Siklus I sudah dilakukan pembelajaran kooperatif Metode Ice Breaking dan pada Siklus II dilakukan perbaikan dengan membentuk kelompok kecil dan mendapat bimbingan dari guru. Hasil tes Siklus II diperoleh 
nilai rata-rata 76,81 . Perbandingan hasil tes dapat dilihat pada Tabel 3.

\section{Tabel 3}

Hasil Tes Siklus I dan Siklus II

\begin{tabular}{lccc}
\hline \multirow{2}{*}{ Nilai } & Siklus & Siklus & $\%$ \\
& I & II & Kenaikan \\
\hline Tinggi & 90 & 95 & 5,56 \\
Rendah & 55 & 60 & 9,09 \\
Rerata & 70,28 & 76,81 & 9,29 \\
\hline
\end{tabular}

Sumber : Data primer (2017)

Berdasarkan Tabel 3, dapat diketahui bahwa ada kenaikan nilai tertinggi dari Siklus I ke Siklus II sebesar 5 atau $5,56 \%$ dan untuk nilai terendah ada kenaikan 5 atau 9,09\%, juga untuk nilai rata-rata ada kenaikan 6,53 atau 9,29\%. Refleksi tindakan mengenai ketuntasan belajar juga dapat dilihat dari perkembangan pencapaian ketuntasan belajar dari Siklus I dan Siklus II, yang dapat dilihat pada Tabel 4.

\section{Tabel 4}

Jumlah Siswa yang tuntas pada Siklus I dan Siklus II

\begin{tabular}{lcc}
\hline Tahap & Frekuensi & $\begin{array}{c}\% \\
\text { Kenaikan }\end{array}$ \\
\hline Siklus I & 20 & 55,56 \\
Siklus II & 31 & 86,11 \\
\hline Ada kenaikan & 11 & 30,56 \\
\hline
\end{tabular}

Sumber : Data primer (2017)

Berdasarkan Tabel 4 dapat diketahui bahwa jumlah siswa yang tuntas belajar antara Siklus I dengan Siklus II setelah diadakan perubahan penggunaan pembelajaran kooperatif Metode Ice Breaking mengalami kenaikan sebesar 11 atau 30,56\%. Jumlah siswa yang tuntas pada Siklus I dengan KKM 75 sebanyak 20 siswa atau 55,56\% dari total siswa sedangkan pada Siklus II jumlah siswa yang tuntas ada 31 siswa atau $86,11 \%$ total siswa. Jumlah siswa yang belum tuntas mengalami penurunan dari 16 siswa menjadi 5 siswa.
Refleksi tindakan hasil motivasi ini dilakukan dengan membandingkan hasil pengamatan mengenai keaktifan, minat dan perhatian sebagai unsur motivasi selama proses pembelajaran antara Siklus I dan Siklus II. Perbandingan unsur motivasi antara Siklus I dengan Siklus II dapat dilihat pada Tabel 5.

Tabel 5

Motivasi Siklus I dan Siklus II

\begin{tabular}{lrrr}
\hline $\begin{array}{c}\text { Unsur } \\
\text { Motivasi }\end{array}$ & $\begin{array}{c}\text { Siklus } \\
\text { I }\end{array}$ & \multicolumn{1}{c}{$\begin{array}{c}\text { Siklus } \\
\text { II }\end{array}$} & $\begin{array}{c}\% \\
\text { Kenaikan }\end{array}$ \\
\hline Aktif & 10 & 30 & 200 \\
Minat & 16 & 28 & 75 \\
Perhatian & 22 & 34 & 54,5 \\
\hline
\end{tabular}

Sumber : Data primer (2017)

Hasil pengamatan teman sejawat pada Siklus I nampak 10 siswa yang aktif, 16 siswa yang minat dan 22 siswa yang perhatian. Pada siklus II setelah ada perbaikan dalam pembelajaran kooperatif Metode Ice Breaking, terdapat 30 siswa yang aktif, terdapat 28 siswa yang minat dan terdapat 34 siswa yang perhatian.

Terdapat peningkatan motivasi belajar yang dilihat dari keaktifan, minat dan perhatian antara Siklus I dan Siklus II. Untuk keaktifan ada kenaikan sebesar 20 atau $200 \%$, untuk minat ada kenaikan sebesar 12 atau $75 \%$ dan untuk perhatian ada kenaikan sebesar 12 atau 54,55\%.

Pada kondisi awal pembelajaran siswa banyak yang tidak aktif, pada siklus I motivasi belajar meningkat karena keaktifan, minat dan perhatian siswa semakin meningkat. Berdasarkan hasil pengamatan dalam kegiatan pembelajaran pada Siklus II, dengan memperbaiki tindakan kelas mampu meningkatkan motivasi belajar siswa. Hal ini terlihat dari keaktifan, minat dan perhatian siswa bertambah sangat signifikan. Dari 36 siswa hanya 6 siswa yang tidak aktif dan tidak minat namun semua memperhatikan dengan baik. 


\section{KESIMPULAN DAN SARAN}

\section{Kesimpulan}

Berdasarkan hasil penelitian tindakan kelas maka dapat disimpulkan bahwa terdapat peningkatan motivasi dan hasil belajar siswa sebelum dan sesudah dilaksanakan ice breaking. Siswa menunjukkan minat dan perhatian lebih besar dalam kegiatan belajar yang ditunjukkan dengan perilaku keaktifan menjawab pertanyaan, besarnya minat dalam mengikuti pelajaran dan perhatian yang besar terhadap mata pelajaran Ekonomi khususnya materi masalahmasalah ekonomi. Hasil belajar siswa mengalami peningkatan, yaitu 62,08 pada kondisi awal, 70,28 pada Siklus I, dan 76,81 pada Siklus 2. Selain itu, jumlah siswa yang memenuhi KKM juga meningkat, yaitu 10 siswa pada kondisi awal, 20 siswa pada Siklus I, dan 31 siswa pada Siklus II.

\section{Saran}

Berdasarkan kesimpulan di atas, maka peneliti memberikan saran-saran sebagai berikut: guru harus kreatif dan berani melakukan inovasi pembelajaran dengan melakukan sentuhan aktivitas di luar rutinitas proses pembelajaran. Guru perlu melakukan aktivitas ice breaking dalam proses pembelajaran sesuai dengan kondisi dan kebutuhan siswa, untuk memecahkan kebekuan suasana belajar di kelas maupun di luar kelas, sehingga proses interaksi interpersonal, antar personal dan kelompok antara guru dan siswa bisa lebih baik, sehingga proses pembelajaran dapat berlangsung lebih baik.

\section{DAFTAR PUSTAKA}

Arikunto, S. (1999). Prosedur Penelitian Suatu Pendekatan Praktek. Jakarta : Rineka Cipta.

Hamalik, O. (1990). Kurikulum dan Pembelajaran. Jakarta: PT. Bumi Aksara.

Sudjana. (2005). Penilaian Hasil Proses Belajar Mengajar. Jakarta: Ganeca Exact.

Kurniasih, A. N., Alarifin D. H. (2015). Penerapan Ice Breaking (Penyegar Pembelajaran) Untuk Meningkatkan Hasil Belajar IPA Siswa Kelas VIIIA MTsN AnNur Pelopor Bandarjaya Tahun Pelajaran 2013/2014. Jurnal Pendidikan Fisika. III(1).

Irachmat, M. R. (2015). Peningkatan Perhatian Siswa Pada Proses. Pembelajaran Kelas Iii Melalui Permainan Icebreaking Di.SDN Gembongan. Jurnal Pendidikan Guru Sekolah Dasar. Edisi 2 Tahun ke IV Januari 2015.

\section{BIODATA PENULIS}

Anik Hastiyaningsih, lahir 28 Februari 1967 di Pati Jawa Tengah. Pendidikan Magister Sains Universitas Stikubank Semarang. Saat ini bekerja sebagai Guru Ekonomi di SMA N 3 Pati. 